\title{
Phytochemicals, Total Phenolic and Flavonoid Contents and Radical Scavenging Activities of Crotalaria Retusa, Clerodendrum Volubile Leaf Extracts and Biogas Slurry of Cassava Peels
}

Oluwaseyi Olaniyan ( $\square$ olaniyanoluwaseyi74@gmail.com )

Osun State University, Osogbo

Ebenezer Ajayi

Osun State University, Osogbo

Oluwaseun Oladele

Osun State University, Osogbo

Simeon Adenrele

Osun State University, Osogbo

Johnson Oladele

Osun State University, Osogbo

Olorunfemi Molehin

Ekiti State University, Ado-Ekiti

Bola Afolabi-Balogun

Fountain University

\section{Babatunde Akinde}

Osun State University, Osogbo

Omotade Oloyede

Ekiti State University, Ado-Ekiti

\section{Research Article}

Keywords: Phytochemicals, Oxidative stress, Antioxidants, Crotalaria retusa, Clerodendrum volubile, Cassava Biogas Slurry

Posted Date: July 26th, 2021

DOl: https://doi.org/10.21203/rs.3.rs-638563/v1

License: (c) (1) This work is licensed under a Creative Commons Attribution 4.0 International License. Read Full License 


\section{Abstract}

Well established are the destructive effects of cellular oxidative damage due to oxidative stress on animal and human health. The prophylactic use of plant-derived bioactive agents in the amelioration and treatment of chronic diseases induced by free radical and oxidative stress is a promising therapeutic approach. This present study investigates the phytochemical constituents, in vitro antioxidant and free radical scavenging abilities of Crotalaria retusa leaves, Clerodendrum volubile leaves and cassava biogas slurry. The total phenolic and flavonoid contents of the extracts were also determined. The phytochemicals, phenolic and flavonoid contents and antioxidant potentials of the extracts, including reducing power, inhibition of hydrogen peroxide, hydroxyl radical production, and DPPH radical scavenging, were performed using standard assays. Our results show terpenoids, saponins, cardiac glycosides, flavonoids and tannins in the various extracts. In vitro, antioxidant assay results also reveal that the extracts' free radical scavenging abilities are significantly high compared with standard antioxidants used: tannic and ascorbic acids. The results also show that the extracts demonstrated elevated antioxidant activities positively correlated with the total flavonoid and phenolic contents. This work demonstrated that the extracts possessed significant antioxidant activities over standard ones, thus, suggesting the extracts as sources of natural antioxidants that could have considerable therapeutic relevance in preventing and inhibiting the progression of diseases associated with oxidative stress.

\section{Introduction}

Oxidative stress is a devastating phenomenon that affects humans. An imbalance between the cellular production of reactive oxygen species and cells' ability to scavenge them is the culprit of an array of neurodegenerative, heart and several other age-related diseases [1]. The reactive oxygen and nitrogen species, including superoxide $\left(\mathrm{O}_{2}^{-}\right)$, hydroxyl $(\mathrm{OH})$, peroxyl $\left(\mathrm{RO}_{2}\right)$, and alkoxyl $\left(\mathrm{RO}^{-}\right)$, nitric oxide $\left(\mathrm{NO}^{-}\right)$, peroxynitrite $\left(\mathrm{ONOO}^{-}\right)$, nitrogen dioxide $\left(\mathrm{NO}_{2}\right)$, cause oxidative damage of cellular components such as lipids, proteins and nucleic acids leading to cellular death either via necrosis or apoptosis [2]. This catastrophe is a natural consequence of the biological production of energy, the severity of which can become more worsened due to depletion of cellular antioxidant defence systems [3].

All biological systems have evolved to possess inherent antioxidant defence mechanisms to counteract and protect against oxidative damages. However, there is often a need for the consumption of dietary antioxidants, especially during illnesses. Consequently, the use of naturally occurring phytochemicals, which are known to trigger antioxidant responses, has been proposed as a practical therapeutic approach for these chronic diseases [4].

Moreover, literature search also confirmed the efficacies of phytochemicals, antioxidants, and vitamins in the amelioration and treatment of complications from excessive oxidative stress $[5,6]$.

Farombi et al. [7] described antioxidants as compounds that can delay or inhibit the oxidation of biomolecules by inhibiting the initiation or propagation of oxidative chain reactions and which can thus 
prevent or repair the damage done to the body's cells by reactive oxygen species. Some of these phytochemicals, such as flavonoids from medicinal plants, have been reported to be safe while showing other pharmacological actions, in addition to their antioxidant properties, including anticarcinogenic, antimutagenicity, antibacterial, antiviral, and anti-inflammatory effects [8].

The plant Crotalaria retusa L., commonly known as Devil Bean, is used traditionally as both food and medicine. Its medicinal value was reported to prevent cough, dyspepsia, fever, cardiac disorders, stomatitis, diarrhoea, scabies and impetigo. Locally, people use an infusion of the plant for bathing children to treat skin infections and thrush [9].

Clerodendrum volubile P. Beauv. (Verbenaceae), also known as "magic leaf" or "white butterfly leaf", is native to Nigeria's southern part. The leaf's traditional usage includes treatment of arthritis, rheumatism, dropsy, swelling, oedema, gout, and pain [10]. Cassava (Manihot esculenta Crantz), popularly called Mandioca and Tapioca, is a popular tropical staple of economic importance. The peel is a waste product majorly used as animals' feeds [11]. The cassava tuber peel's biogas slurry was selected to see whether the Slurry would contain promising biotransformation products.

Previous works have explored the prophylactic use of plant-derived bioactive agents to treat chronic diseases such as diabetes mellitus, cancer and cardiovascular diseases. Amongst these classes of bioactive agents, the focus was on the anti-inflammatory and antioxidant properties of polyphenols found in various plants [12]. Based on this background, this study was designed to investigate the phytochemical contents and antioxidant properties of ethanolic and hot water infusion extract of Crotalaria retusa L., Clerodendrum volubile P. Beauv., and Cassava (Manihot esculenta Crantz) Biogas Slurry.

\section{Materials And Methods}

\section{Chemicals and Reagents}

Folin-Ciocalteu's reagent, $\mathrm{HCl}$, methanol, gallic acid, $\mathrm{H}_{2} \mathrm{SO}_{4}, \mathrm{Na}_{2} \mathrm{CO}_{3}$, aluminium chloride, potassium acetate, potassium persulphate, sodium nitroprusside, hydrogen peroxide, sulphanilic acid, glacial acetic acid, naphthyl ethylenediamine dichloride, NADH were all purchased from Merck, USA. DPPH (1,1diphenyl-1,2-picryl hydrazyl), TPTZ (2,4,6, -tripyridyl-s-triazine), Ferrozine, Deoxyribose Sigma (St Louis, MO, USA). Trichloroacetic acid (TCA), L-Ascorbic acid, and all other chemicals and reagents used were of analytical grade.

\section{Plants Collection}

Crotalaria retusa and Clerodendrum volubile leaves were collected within Oke-Baale Area, Osogbo, Osun State, Nigeria in May 2019, while dry cassava peels obtained from Oyo town, Oyo State, Nigeria in February 2019. Both leaves and the dry cassava peels were transferred to Osun State University herbarium. A permit for the collection of the vegetal materials was obtained and in accordance with the 
national plant collection guidelines of the Forestry Research Institute of Nigeria (FRIN) - Herbal Garden, Jericho Hills, Ibadan, Oyo State, Nigeria. The plants were identified by Dr Mahboob Jimoh at the herbarium of the Department of Biological Sciences, Osun State University, Osogbo, Osun State, Nigeria, with the voucher numbers: PBO/UNIOSUN/18/0027, PBO/UNIOSUN/18/0028, PBO/UNIOSUN/18/0029, respectively and after that deposited at the herbarium of the Department of Biological Sciences, Osun State University, Osogbo, Osun State, Nigeria.

\section{Preparation of Extracts}

The leaves of Crotalaria retusa L. and Clerodendrum volubile P. Beauv were air-dried at room temperature for four (4) weeks and further pulverized to powder form. The powered form samples and the bio-slurry ( $100 \mathrm{~g}$ each of the powder form and $100 \mathrm{ml}$ of bio-slurry) exhaustively extracted by cold-maceration extraction method using $100 \mathrm{ml}$ of $95 \%$ ethanol and hot water infusion method at $100{ }^{\circ} \mathrm{C}$ using $100 \mathrm{ml}$ distilled water for 48 hours. The resulting extract fractions passed through a mesh sieve $(1 \mathrm{~mm})$, filtered using Whatman filter paper no. 1, and then concentrated using a rotary evaporator (LIDAi.DNA XMT $\mathrm{J} 7000 / \mathrm{RE} 52-3)$. After which, the various concentrations $(250 \mu \mathrm{g} / \mathrm{ml}, 500 \mu \mathrm{g} / \mathrm{ml}$ and $1000 \mu \mathrm{g} / \mathrm{ml})$ prepared for the in vitro assays.

\section{Phytochemical Analyses}

The qualitative phytochemicals screening for the presence of alkaloids, resins, tannins, saponins, flavonoids, glycosides, phenols, anthraquinones, cardiac glycosides, steroids, phlorotannins, and reducing sugars in the extracts were done using standard methods.

\section{Evaluation of Alkaloids}

One $\mathrm{ml}$ of extracts was shaken with dilute $\mathrm{HCl}$ for two minutes and the filtrates treated with Mayer's reagent (mercuric potassium iodide). The formation of a yellow precipitate indicated the presence of alkaloids [13].

\section{Evaluation of Steroid (Salkowski Test)}

Concentrated $\mathrm{H}_{2} \mathrm{SO}_{4}$ was added to $1 \mathrm{ml}$ of extract. The formation of wine-red colour indicates the presence of sterols [13].

\section{Evaluation of Glycosides}

A small amount of extract was taken in $1 \mathrm{ml}$ of water, and a few drops of aqueous sodium hydroxide were added. The yellow colour was considered as an indication of the presence of glycosides [13].

\section{Evaluation of Saponins (Froth Test)}

Fifteen millilitres of distilled water were added to $100 \mathrm{mg}$ of the crude extract and filtered into the test tube. The mixture was shaken for 10 min until the formation of stable persistent froth. Formation of stables five-minute persistent froth indicated the presence of saponins [14]. 


\section{Evaluation of Tannins (Ferric Chloride Test)}

The ethanol was added to the crude extract $(10 \mathrm{mg} / \mathrm{ml})$, and the mixture was filtered. A two-millilitre filtrate was transferred into the test tube, and few drops of $0.1 \% \mathrm{FeCl}_{3}$ were added. The brownish-green colouration of the test group was interpreted as the presence of tannins [15].

\section{Evaluation of Phenolic Compounds (Ferric Chloride Test)}

The crude extracts were mixed with ethanol $(10 \mathrm{mg} / \mathrm{ml})$, and the solution was filtered. A two-millilitre filtrate was pipetted into the test tube, followed by the addition of $5 \mathrm{ml}$ distilled water. Four drops of $5 \%$ $\mathrm{FeCl}_{3}$ were dripped into the filtrate. The formation of dark green precipitate showed the presence of phenolic compounds [14].

\section{Evaluation of reducing sugars}

Two hundred milligrams of the extracts were shaken with distilled water and filtered. The filtrate was boiled with drops of Fehling's solution $A$ and $B$ for two minutes. An orange precipitate on boiling with the Fehling's solution indicated the presence of reducing sugars [14].

\section{Evaluation of Terpenoids (chloroform test)}

One hundred milligrams of the crude extract were dissolved in the chloroform $5 \mathrm{ml}$ and filtered into the test tube. $3 \mathrm{ml}$ of $\mathrm{H}_{2} \mathrm{SO}_{4}$ was carefully added along the side of the test tube. The reddish-brown colour at the interface of the two phases characterised the presence of terpenoids [15].

\section{Bioactive Quantitative Assays}

The quantitative analysis of the bioactive compounds present in the sample was determined by spectrophotometry using tannic acid, catechin, and gallic acid as standards.

\section{Determination of Total Phenolic Contents}

The number of total phenolics in the extract was determined with Folin-Ciocalteu's reagent according to the method of Singleton and Rossi, [16] with the slight modification described by Ajayi et al. [17]. Briefly, 1 $\mathrm{ml}$ of extract solution $(5 \mathrm{mg} / \mathrm{ml})$ was added in a $100 \mathrm{ml}$ volumetric flask that contained about $60 \mathrm{ml}$ distilled water. Then $5.0 \mathrm{ml}$ of Folin-Ciocalteu's reagent was added, and the content of the flask was mixed thoroughly. After 1-8 min, $15.0 \mathrm{ml} \mathrm{Na}_{2} \mathrm{CO}_{3}(20 \%)$ was added, and the volume was made up to 100 $\mathrm{ml}$ using distilled water. The mixture was allowed to stand for $2 \mathrm{hr}$ with intermittent shaking. The absorbance was measured at $760 \mathrm{~nm}$ using a UV-Vis spectrophotometer (Jenway 6100, Dunmow, Essex, UK).

The total phenolic content was determined as milligrams of gallic acid equivalent (GAE) using the equation $\left(y=0.0086 x+0.0105, R^{2}=0.958\right)$ obtained from the standard gallic acid calibration graph. 


\section{Total Phenolic content $=\underline{\text { Absorbance reading for test } \times \text { Standard concentration }}$}

\section{Absorbance reading for standard \\ Determination of Total Flavonoids}

The total flavonoid contents of the extracts were measured by $\mathrm{Al}_{2} \mathrm{Cl}_{3}$ colourimetric assay [18]. Briefly, to $0.5 \mathrm{ml}$ of sample, $0.5 \mathrm{ml}$ of $2 \% \mathrm{AlCl}_{3}$ ethanol solution was added. After one hour at room temperature, the absorbance was measured at $420 \mathrm{~nm}$. The yellow colour indicated the presence of flavonoids. Extract samples were evaluated at a final concentration of $1 \mathrm{mg} / \mathrm{ml}$. All determinations were carried out in duplicates. The quantity of flavonoids in plant extract was determined in catechin equivalent (CE) using the equation $\left(y=0.0135 x+0.0085, R^{2}=0.941\right)$ obtained from the standard catechin calibration graph.

\section{Total Flavonoids Content $=\underline{\text { Absorbance reading for test } \times \text { Standard concentration }}$}

\section{Absorbance reading for standard}

\section{In-vitro Antioxidant Assays \\ Reducing Power Assay}

The reducing power of various extracts was based on Fe (III) to Fe (II) transformation according to the method of Oyaizu, [19]. The Fe (II) was monitored by measuring the formation of Perl's Prussian blue at $700 \mathrm{~nm}$, using vitamin $\mathrm{C}$ and tannic acid as standards. The extractor standard $(100 \mu \mathrm{g} / \mathrm{ml})$ was mixed with phosphate buffer $\left(\mathrm{pH} \mathrm{6.6)}\right.$ ) and potassium ferricyanide. The mixture was incubated at $50^{\circ} \mathrm{C}$ for 20 min. Trichloroacetic acid ( $2.5 \mathrm{ml}$ of $10 \%)$ was added to the mixture. A portion of the resulting mixture was mixed with $\mathrm{FeCl}_{3}(0.5 \mathrm{ml}$ of $0.1 \%)$ and the absorbance was measured at $700 \mathrm{~nm}$ in a spectrophotometer. Higher absorbance of the reaction mixture indicated the reductive potential of the extract.

\section{Hydrogen Peroxide Scavenging Assay}

The ability of the extract to scavenge hydrogen peroxide was determined according to the method of Ilhami et al. [20]. A solution of hydrogen peroxide $(40 \mathrm{mM})$ was prepared in phosphate buffer $(\mathrm{pH} 7.4)$. Different concentrations of plant extract were added to a hydrogen peroxide solution $(0.6 \mathrm{ml}, 40 \mathrm{mM})$. The absorbance of hydrogen peroxide at $230 \mathrm{~nm}$ was determined after 10 min against a blank solution containing phosphate buffer without hydrogen peroxide. The percentage inhibition of hydrogen peroxide of extracts and standard compounds (Vitamin C and Tannic acid) was calculated using the following formula:

\section{$\%$ inhibition $\left[\mathrm{H}_{2} \mathrm{O}_{2}\right]=\left[\left(\mathrm{A}_{0}-\mathrm{A}_{1}\right) / \mathrm{A}_{0}\right] \times 100$}


A0 was the absorbance of the control, and A1 was the absorbance in the sample of extract and standards.

\section{Hydroxyl Radical Scavenging Assay}

Hydroxyl radical scavenging activity of the extracts was determined by the method of Klein et al. [21] with a slight modification. $0.5 \mathrm{ml}$ of extract or standard (Vitamin $\mathrm{C}$ and Tannic acid) at different concentration was taken in test tubes. $1 \mathrm{ml}$ of Fe-EDTA solution ( $0.13 \%$ ferrous ammonium sulphate and $0.26 \%$ EDTA), $0.5 \mathrm{ml}$ of $0.018 \%$ EDTA solution, $1 \mathrm{ml}$ of $0.85 \%$ DMSO solution and $0.5 \mathrm{ml}$ of $22 \%$ ascorbic acid were added into the test tubes. The test tubes were capped tightly and warm at $85^{\circ} \mathrm{C}$ for 15 minutes into the water bath. After incubation, the test tubes were uncapped, and a $0.5 \mathrm{ml}$ ice-cold TCA (17.5\%) was added to each test tube immediately. $3 \mathrm{ml}$ of Nash reagent $(7.5 \mathrm{~g}$ of ammonium acetate, $300 \mu \mathrm{l}$ glacial acetic acid and $200 \mu \mathrm{l}$ acetylacetone were mixed and made up to $100 \mathrm{ml}$ ) was added to all the tubes and incubated at RT for 15 minutes. Absorbance was taken in UV-spectrophotometer at $412 \mathrm{~nm}$ wavelength. Percentage hydroxyl radical scavenging (\% HRSA) activity was calculated using the following equation:

\section{$\% H R S A=\left\{\left(A_{0}-A_{1}\right) / A_{0}\right\} \times 100$}

Where $A_{0}$ is the absorbance of the control, and $A_{1}$ is the absorbance of the extracts/standard.

\section{DPPH - Radical Scavenging Assay}

The radical scavenging activity of plant extracts was measured as described by Mensor et al. [22]. The stable 2, 2 diphenyl-1-picryldydrazyl (DPPH) radical was used to determine the free radical scavenging activities of the extracts. A portion $(1 \mathrm{ml})$ each of the different concentrations $(40-2000 \mu \mathrm{g} / \mathrm{ml})$ of the extracts or standard (Vitamin $\mathrm{C}$ and Tannic acid) in test tubes was added to $1 \mathrm{ml}$ of $1 \mathrm{mM}$ DPPH in methanol. The mixtures were vortexed and then incubated in a dark chamber for 30 min, after which the absorbances were measured at $517 \mathrm{~nm}$ against a DPPH control containing only $1 \mathrm{ml}$ of methanol in place of the extract. All calculations were carried out in triplicates. The inhibition of DPPH was calculated as a percentage using the expression:

\section{$\% I=\left[\left(A_{\text {control }}-A_{\text {sample }}\right) / A_{\text {control }}\right] \times 100$}

Where \% I is the inhibition of the DPPH free radicals in percentage; $A_{\text {control }}$ is the absorbance of the control reaction containing all reagents except the test compound, and $A_{\text {sample }}$ is the absorbance of the test compound.

\section{Statistical Analysis}

The results were analysed using SPSS Version 12. Data were expressed as mean \pm standard error of the mean (mean $\pm S D$ ). The student's t-test was employed to compare two sets of data while $p<0.05$ was considered statistically significant. 


\section{Results}

The presence of steroids, flavonoids, saponins, glycosides, tannins/phenols was confirmed in one or both extracts of CR. Alkaloids, steroids, flavonoids, saponins, reducing sugars and terpenoids were found in one or both extracts of $\mathrm{CL}$, while alkaloids, flavonoids, saponins, glycosides and terpenoids were detected in one or both extracts of CSW (Table 1).

Table 1

Phytochemical Screening of the Extracts

\begin{tabular}{|c|c|c|c|c|c|c|c|}
\hline Phytochemicals & Specific Test & CR-EE & CR-I & CL-EE & CL-I & CSW-EE & csw- \\
\hline Alkaloids & Mayer's test & - & - & + & + & + & + \\
\hline \multirow[t]{2}{*}{ Steroid } & Sulphuric acid test & - & + & - & + & + & + \\
\hline & Salkowski test & - & + & - & + & + & + \\
\hline Flavonoids & Sulphuric acid test & + & + & + & + & + & + \\
\hline Saponins & Froth test & + & + & + & + & $+*$ & + \\
\hline Glycosides & General test & + & + & - & - & $+*$ & + \\
\hline Tannins / Phenol & Ferric chloride test & + & - & - & - & - & - \\
\hline Reducing Sugar & Benedict test & - & - & - & + & - & - \\
\hline Terpenoids & Chloroform test & - & - & - & + & + & - \\
\hline
\end{tabular}

The total phenolic content was very high in the hot water infusion extract of CSW followed by the ethanolic extract of $\mathrm{CL}$ and the hot water infusion of CR (Fig. 1), while the total flavonoid content was very highest in the ethanolic extracts of $\mathrm{CR}, \mathrm{CL}$, and the hot water infusion of $\mathrm{CR}$, respectively (Fig. 2). The ferric reducing antioxidant power of the infusion extract of CRL was low at $200 \mu \mathrm{g} / \mathrm{ml}$, but high for both extracts of all three samples at $500 \mu \mathrm{g} / \mathrm{ml}$ (Fig. 3).

Both extracts of $\mathrm{CR}$ possess high $\mathrm{H}_{2} \mathrm{O}_{2}$-scavenging potential compared to the others whose activities remained low at $250 \mu \mathrm{g} / \mathrm{ml}, 500 \mu \mathrm{g} / \mathrm{ml}$ and $1000 \mu \mathrm{g} / \mathrm{ml}$ (Fig. 4). Only the ethanolic extracts of CR and CSW possess high hydroxyl radical scavenging power; whereas the infusion extract of $C L$ and the ethanolic extract of CSW showed high DPPH radical scavenging ability compared to tannic acid (Fig. 5).

\section{Discussion}

Antioxidants and free radical assays have been the most promising approaches to ascertain medicinal plants' biological activities and pharmacological properties [1]. This study confirmes the presence of 
some in vitro antioxidants and free radical scavenging activities of ethanolic and hot water infusion of Crotalaria retusa leaves, Clerodendrum volubile leaves, and Cassava (Manihot esculenta Crantz), Biogas Slurry. The preliminary phytochemical analysis of the various extracts used for this study revealed that the extracts contain bioactive compounds such as alkaloids, steroid, flavonoids, saponins, glycosides, tannins / phenol, reducing sugar, and terpenoids.

Flavonoids have been documented to take part in regulating cellular metabolism and detoxification activities against most oxidising molecules due to their present of phenolic hydroxylic groups [23, 24], which have been implicated in the pathogenesis of several diseases. Reports have shown an inverse relationship between stroke, lung cancer and stomach cancer, intake of flavonoids, and coronary heart disease risk [25]. Phenols and polyphenolic compounds, such as flavonoids possess significant antioxidant activities and are ubiquitously present in plant-based foods. Thus, the results of total phenolic and flavonoids contents in Figs. 1 and 2 suggested that they may be the major contributors to the in vitro antioxidant and free radical scavenging activities demonstrated by various extracts used in the study.

The result in Fig. 3 revealed the reducing power of different concentrations of extracts from ethanolic and water infusion of Crotalaria retusa, Clerodendrum volubile, Cassava (Manihot esculenta Crantz) Biogas Slurry compared with vitamin $\mathrm{C}$ and tannic acid. The yellow colouration of the testing mixture changes to green depending on the reducing power of the test specimen. The presence of the reducing agents in the sample solution causes the reduction of the $\mathrm{Fe}^{3+} /$ ferricyanide complex to the ferrous form [26]. Thus, the ferrous ion can be monitored by absorbance measurement at $700 \mathrm{~nm}$. The reducing properties have been documented to exert antioxidant action by donating a hydrogen atom to break the free radical chain [27]. Increasing absorbance at $700 \mathrm{~nm}$ indicates an increase in reducing ability. The various extracts used in the study shows significant reducing power when compared with vitamin $\mathrm{C}$ and tannic acid used as standard antioxidants.

The carcinogenic and mutagenic ability of free radicals is due to the direct interactions of hydroxyl radicals with DNA molecules which play a critical role in the carcinogenesis pathway (cancer formation). Hydroxyl radicals can cause damage to almost every biological cell and can be generated during biotransformation reaction in the body. Superoxide radical is converted by superoxide dismutase to hydrogen peroxide, which can subsequently produce highly reactive hydroxyl radicals in the presence of divalent metal ions, such as iron and copper [28]. Results in Fig. 5 showed that the various extracts used in the present study have significant hydroxyl radical scavenging abilities compared with vitamin $\mathrm{C}$ and tannic acid. The hydroxyl radical detoxification may be used in the presence of polyphenols and flavonoids in the extracts.

Hydrogen peroxide scavenging activity of the various concentrations of extracts used in this study was presented in Fig. 4 compared with the standard antioxidants: ascorbic acid and tannic acid. Hydrogen peroxide is a very weak oxidant but can become very toxic when rapidly decomposed into oxygen and water. This may produce hydroxyl radicals $(\mathrm{OH})$ that can initiate lipid peroxidation cause DNA damage 
[29]. Hydrogen peroxide can also inhibit the activities of some enzymes by oxidising their essential thiol ($\mathrm{SH})$ groups. The various extracts used in this study efficiently scavenged hydrogen peroxide, which may be attributed to phenolic groups that could donate electrons to hydrogen peroxide, thereby neutralising it into water.

Hydrogen donating ability is one of the indices to ascertain the antioxidant properties of phytochemicals. Radical scavenging activities are critical to prevent the damaging role of free radical in different diseases. DPPH is known to abstract labile hydrogen, and the ability to scavenge the DPPH radical is related to the inhibition of lipid peroxidation [30]. The figure shows that the various extracts used in this study have significant free radical scavenging activities compared with standard antioxidants: tannic acid and ascorbic acid. All the extracts show higher scavenging ability over vitamin $\mathrm{C}$. This indicates that they could better free radical scavenging ability and inhibit lipid peroxidation more efficiently than vitamin C.

\section{Conclusion}

The in vitro free radical scavenging activities reveal that all three extracts have significant radicals scavenging properties on hydrogen peroxide, hydroxyl radicals, and DPPH. The flavonoids and phenolic contents corroborated the high reducing power of the various extracts. Altogether, this work demonstrated that the extracts possessed significant antioxidant activities over well-characterised standard antioxidants, thus, suggesting the extracts as sources of natural antioxidants that could have high therapeutic relevance in preventing or inhibiting the progression of diseases associated with oxidative stress.

\section{Abbreviations}

$\mathrm{HCl}$ - hydrochloric acid, $\mathrm{H}_{2} \mathrm{SO}_{4}$ - sulphuric acid, $\mathrm{Na}_{2} \mathrm{CO}_{3}$ - sodium bicarbonate, $\mathrm{NADH}$ - DPPH - 1,1diphenyl-1,2-picryl hydrazyl, TPTZ - 2,4,6,-tripyridyl-s-triazine, TCA - Trichloroacetic acid, VIT C: Vitamin C, TN AC: Tannic acid, CR-I: Crotalaria retusa infusion, CR-EE: Crotalaria retusa ethanolic extract, CL - EE: Clerodendrum volubile ethanolic extract, CL- I: Clerodendrum volubile infusion, CSW - EE: Cassava Biogas Slurry ethanolic extract, CSW - I: Cassava Biogas Slurry infusion.

\section{Declarations}

\section{Ethics approval and consent to participate}

Not applicable as no humans were recruited for the study

\section{Consent for publication}




\section{Availability of data and material}

The datasets used and/or analyzed during the current study are available from the corresponding author on reasonable request.

\section{Competing interests}

The authors declare no competing interests

\section{Conflict of interests}

The authors declare no conflict of interest.

\section{Authors' Contributions:}

AEIO, MOR, A-BNB, ASB and OOI designed the study. OOP, OOT, ASO, OJO and A-BNB conducted the experiments. OOP, OJO, MOR and AEIO wrote the manuscript, AEIO, MOR, ASB, A-BNB and OOI read and corrected the manuscript. All authors read and approved the submission of this manuscript.

\section{Funding}

This study was self-funded by the authors

\section{Acknowledgements}

Not applicable

\section{Authors' information}

Provided from the title page

\section{References}

1. Akinmoladun, A. C., Obuotor, E. M. \& Farombi, E. O. Evaluation of Antioxidant and Free Radical Scavenging Capacities of Some Nigerian Indigenous Medicinal Plants. Journal of Medicinal Food, 13 (2), 444-451 (2010). 10.1089=jmf.2008.0292 
2. Farombi, E. O., Akanni, O. O. \& Emerole, G. O. Antioxidant and Scavenging Activities of Flavonoid Extract (Kolaviron) of Garcinia kola Seeds. Pharm. Biol, 40 (2), 107116 https://doi.org/10.1076/phbi.40.2.107.5838 (2002).

3. Nwachukwu, I. D. \& Aluko, R. E. Structural and functional properties of food protein-derived antioxidant peptides. Journal of Food Biochemistry, e12761 https://doi.org/10.1111/jfbc.12761 (2019).

4. Acham, I. O., Ukeyima, M. T., Ahemen, S., Girgih, T. A. \& Aluko, R. E. In vitro Antioxidant Properties of Mango Powder Produced from Blends of Brokin and Julie Cultivars Fortified with Yellow Pea protein hydrolysate. American Journal of Food and Nutrition, 6 (3), 60-66 https://doi.org/10.12691/ajfn-6-31 (2018).

5. Devendra, B. N., Srinivas, N. \& Kusuma, S. S. A comparative pharmacological and phytochemical analysis of in vivo \& in vitro propagated Crotalaria species. Asian Pacific J. Tropical Med, 5 (1), $37-$ 41 https://doi.org/10.1016/S1995-7645 (2012).

6. Tan, B. L., Norhaizan, M. E., Liew, W-P-P. \& Rahman, H. S. Antioxidant and oxidative stress: A mutual interplay in age-related diseases. Front. Pharmacol, 9, 1162 https://doi.org/10.3389/fphar.2018.01162 (2018).

7. Farombi, E. O., Adedara, I. A., Ajayi, B. O., Ayepola, O. R. \& Egbeme, E. E. Kolaviron, a Natural Antioxidant and Anti-Inflammatory Phytochemical Prevents Dextran Sulphate Sodium-Induced Colitis in Rats. Basic and Clinical Pharmacology and Toxicology, 113, 49-55 https://doi.org/10.1111/bcpt.12050 (2013).

8. Erukainure, O. L., Oke, O. V., Ajiboye, A. J. \& Okafor, O. Y. Nutritional qualities and phytochemical constituents of Clerodendrum volubile, a tropical non-conventional vegetable. Int. Food Res J, 18, 1393-1399 (2011).

9. Frankel, E. N., Kanner, J., German, J. B., Parks, E. \& Kinsella, J. E. Inhibition of oxidation of human low-density lipoprotein by phenolic substances in red wine., 341, 454-457 https://doi.org/10.1016/0140-6736(93)90206-V (1993).

10. Bravo, L. (1998). Polyphenols: chemistry, dietary sources, metabolism and nutritional significance. Nutr. Rev. 56: 317-333. doi:10.1111/j.1753-4887. 1998.tb01670.x.

11. Hengniran, P. 2010. The future potential of forest and agriculture residues for energy production in Thailand - Strategies for better utilization. PhD thesis, University of Hamburg, Germany.

12. Panche, A. N., Diwan, A. D. \& Chandra, S. R. Flavonoids: an overview. J Nutr Sci, 5, e47 https://doi.org/10.1017/jns.2016.41 (2016).

13. Pant, D. R., Pant, N. D., Saru, D. B., Yadav, U. N. \& Khanal, D. P. Phytochemical screening and study of antioxidant, antimicrobial, antidiabetic, anti-inflammatory and analgesic activities of extracts from stem wood of Pterocarpus marsupium Roxburgh. J. intercult. Ethnopharmacol, 6 (2), 170-176 https://doi.org/10.5455/jice.20170403094055 (2017).

14. Djaafar, Z. \& Ridha, O. M. Phytochemical study of selected medicinal plant, Solanum nigrum, the Algerian desert. Int. Let. Chem., Phys. Astro, 20, 25-30 
https://doi.org/10.18052/www.scipress.com/ILCPA.20.25 (2013).

15. Odeja, O., Obi, G., Ogwuche, C. E., Elemike, E. E. \& Oderinlo, Y. Phytochemical screening, antioxidant and antimicrobial activities of Senna occidentalis (L.) leaves extract. Clinical Phytosci, 1, 6 https://doi.org/10.1186/s40816-015-0007-y (2015).

16. Singleton, V. L. \& Rossi, J. A. Colourimetry of total phenolics with phosphomolybdic-phosphotungstic cid reagents. Am. J. Enol. Vitic, 16 (3), 144-158 (1965).

17. Ajayi, E. I. O., Popoola, G. \& Ojediran, E. Wound healing potential of Nauclea latifolia and Manihot esculenta leaf extracts in type 1 diabetic rats. Afr. J. Tradit. Complement Altern. Med, 13 (1), 1-5 (2016). 10.4314/ajtcam. v13i1.1

18. Ordon, E. Z., Gomez, J. D., Vattuone, M. A. \& Isla, M. I. Antioxidant activities of Sechium edule (Jacq.) swart extracts. Food Chem, 97, 452-458 https://doi.org/10.1016/j.foodchem.2005.05.024 (2006).

19. Oyaizu, M. Studies on product of browning reaction prepared from glucose amine. Japan J Nutr, 44, 307-315 https://doi.org/10.5264/eiyogakuzashi.44.307 (1986).

20. Ilhami, G. I., Haci, A. A. \& Mehmet, C. Determination of in vitro antioxidant and radical scavenging activities of Propofol. Chem Pharmacol Bull, 53 (3), 281-285 (2005).

21. Klein, S. M., Cohen, G. \& Cederbaum, A. I. Production of formaldehyde during metabolism of dimethyl sulphoxide by hydroxyl radical generating system. Biochem, 20, 6006-6012 https://doi.org/10.1021/bi00524a013 (1981).

22. Mensor, L. L. et al. Screening of Brazilian plant extracts for antioxidant activity by the use of DPPH free radical method. Phytother. Res, 15 (2), 127-130 https://doi.org/10.1002/ptr.687 (2001).

23. Kopustinskiene, D. M., Jakstas, V., Savickas, A. \& Bernatoniene, J. Flavonoids as Anticancer Agents. Nutrients, 12 (2), 457 https://doi.org/10.3390/nu12020457 (2020).

24. Bravo, L. Polyphenols: chemistry, dietary sources, metabolism and nutritional significance. Nutr. Reviews, 56, 317-333 https://doi.org/10.1111/j.1753-4887 (1998).

25. Oyewole, O. I. \& Akingbala, P. F. Phytochemical Analysis and Hypolipidemic Properties of Jatropha Tanjorensis Leaf Extract. European Journal of Medicinal Plants, 1 (4), 180-185 https://doi.org/10.9734/EJMP/2011/497 (2011).

26. Mundi, S. \& Aluko, R. E. Inhibitory Properties of Kidney Bean Protein Hydrolysate and its Membrane Fractions Against Renin, Angiotensin Converting Enzyme, and Free Radicals. Austin J Nutri Food Sci, 2 (1), 10082381-10088980 (2014).

27. Gordon, M. H. (1990). The mechanism of antioxidant action in vitro. In Food Antioxidants. Edited by Hudson BJ. London: Elsevier Applied Science, Springer, Dordrecht: pp. 1-pp. 18. doi:10.1007/978-94009-0753-9_1.

28. Thorpe, G. W. et al. Superoxide radicals have a protective role during $\mathrm{H} 2 \mathrm{O} 2$ stress. Mol. Biol. Cell, 24 (18), 2876-2884 (2013). 10.1091/mbc. E13-01-0052

29. Zeghad, N., Ahmed, E., Belkhiri, A., Heyden, Y. V. \& Demey, K. Antioxidant activity of Vitis vinifera, Punica granatum, Citrus aurantium and Opuntia ficus indica fruits cultivated in Algeria. Heliyon, $\mathbf{5}$ 
(4), e01575 (2019). 10.1016/j.heliyon. 2019.e01575

30. Ajayi, E. I., Agarwal, A., Banerjee, U. C. \& Olorunsogo, O. O. Ethanol extract of Manihot esculenta leaf: A potential source of antioxidant, xanthine oxidase and lipase inhibitors. Analele Stiintifice ale Universitatii" Alexandru loan Cuza" din lasi Sec. Il a. Genetica si Biologie Moleculara, 18 (1), 17-23 (2017).

\section{Figures}

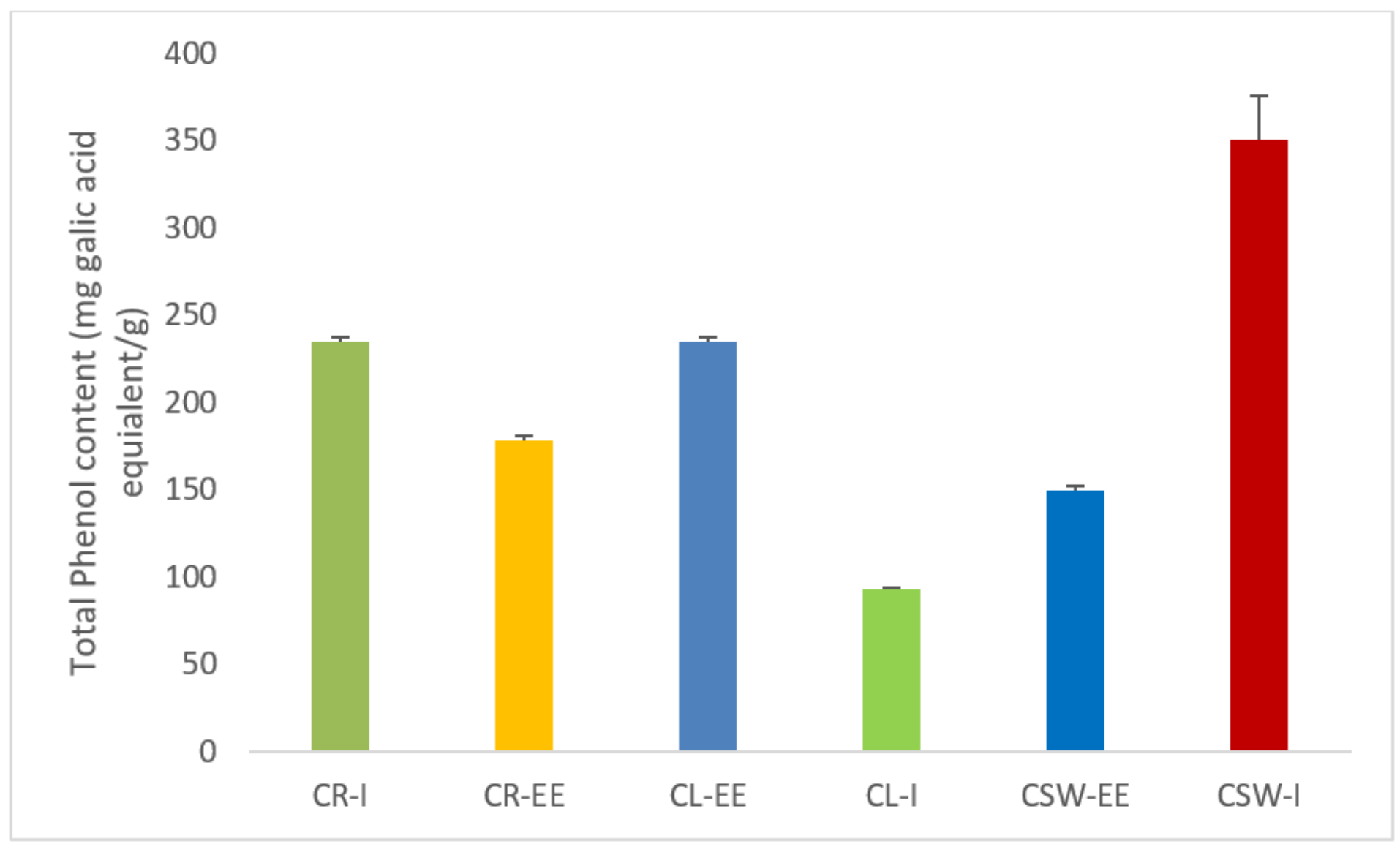

\section{Figure 1}

Total Phenol content of the ethanolic and hot water infusion of Crotalaria retusa, Clerodendrum volubile, cassava biogas slurry extract. Each value represents a mean $\pm S D(n=2)$. CR-EE - Crotalaria Retusa ethanolic extract, CL-EE - Clerodendrum volubile ethanolic extract, $C L-I-$ Clerodendrum volubile infusion, CSW-EE - cassava biogas slurry ethanolic extract, CSW-I - cassava biogas slurry infusion. 
170

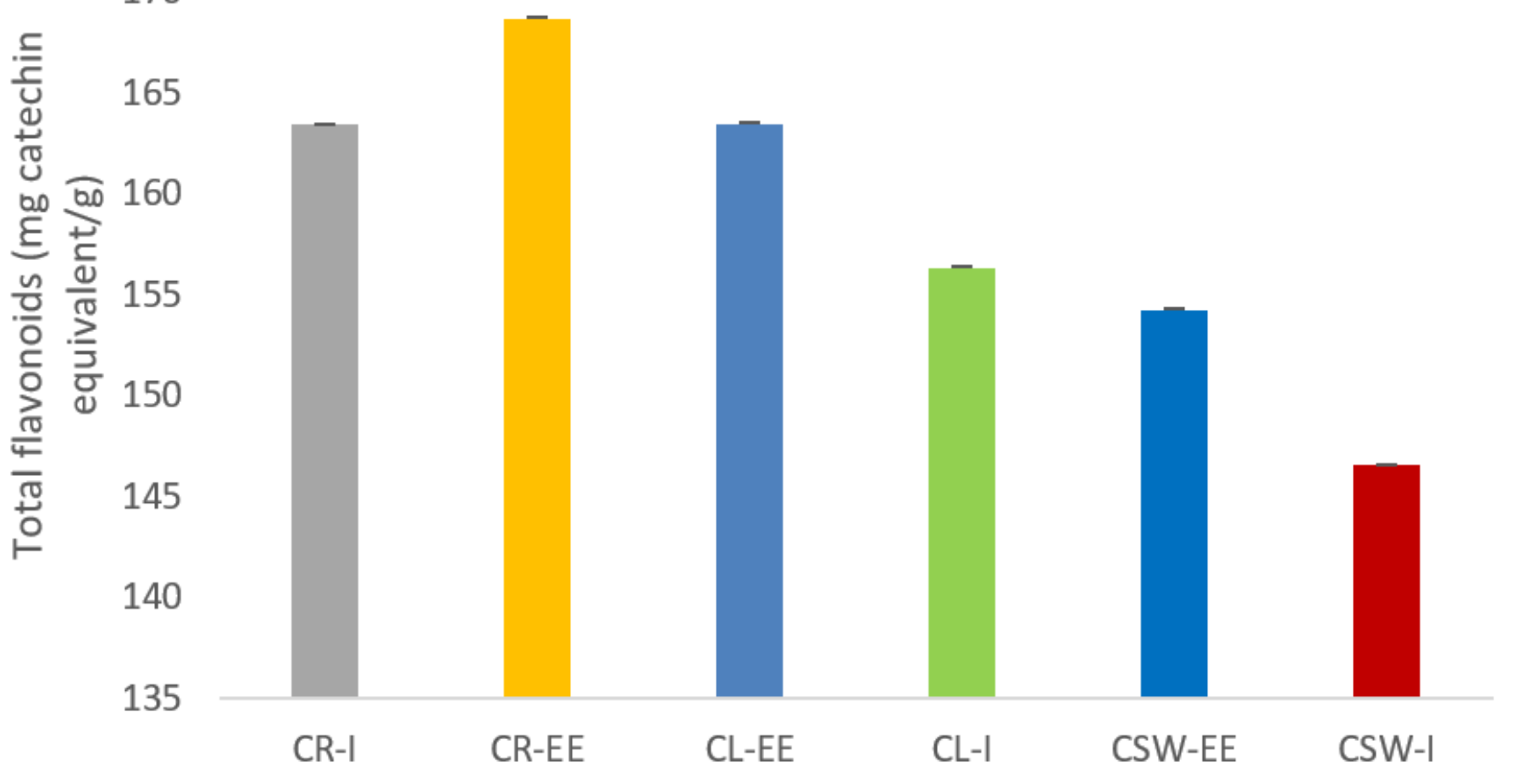

Figure 2

Total Flavonoids content of the ethanolic and hot water infusion of Crotalaria retusa, Clerodendrum volubile, cassava biogas slurry extract. Each value represents a mean $\pm S D(n=2)$. CR-EE - Crotalaria Retusa ethanolic extract, CL-EE - Clerodendrum volubile ethanolic extract, CL-I - Clerodendrum volubile infusion, CSW-EE - cassava biogas slurry ethanolic extract, CSW-I - cassava biogas slurry infusion. 


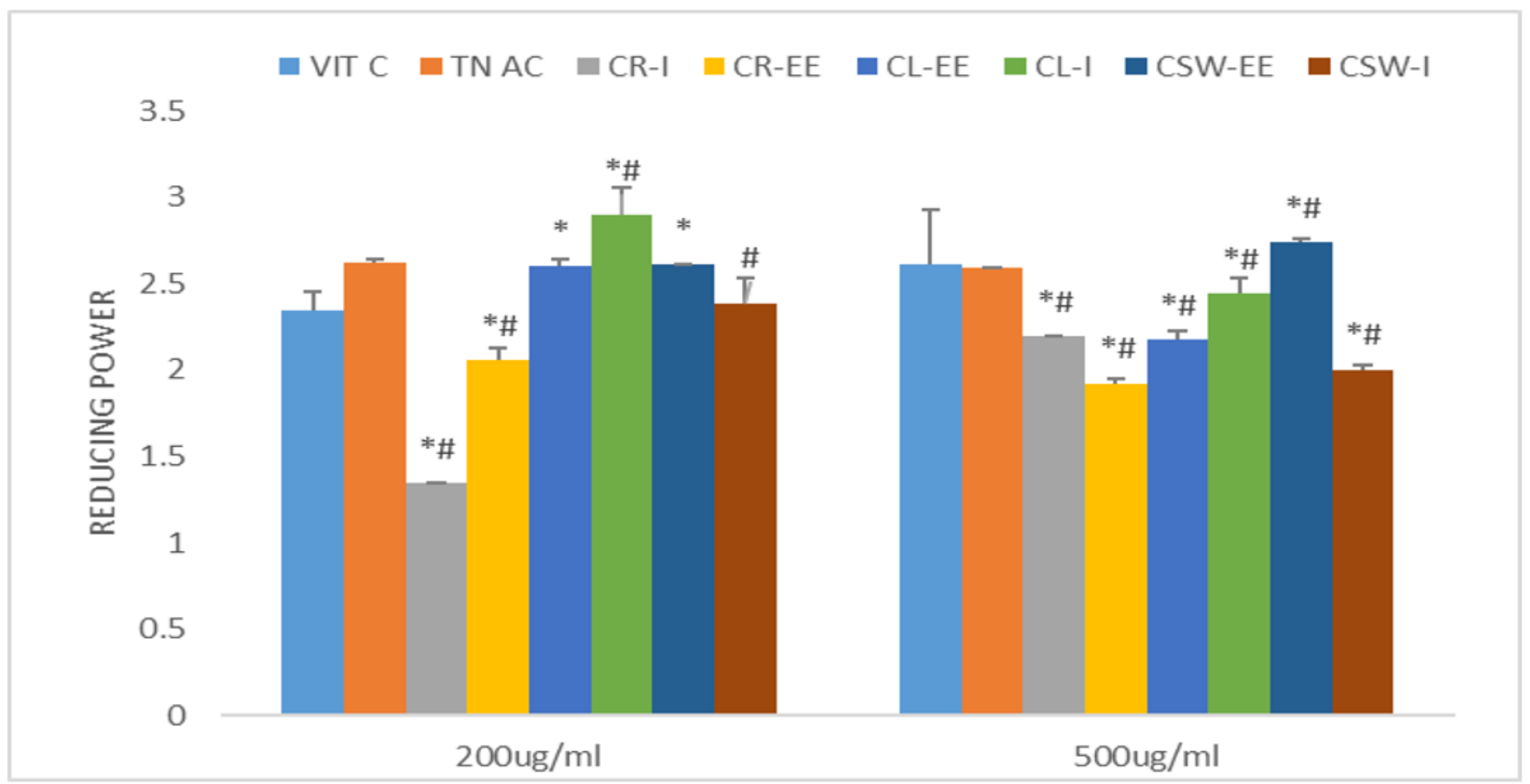

\section{Figure 3}

Free Radical Reducing Power of the ethanolic and hot water infusion of Crotalaria retusa, Clerodendrum volubile, cassava biogas slurry extract. Each value represents a mean $\pm \operatorname{SD}(n=2)$. "*" and "\#" indicate a significant difference in the effects of each sample compared to vitamin $C$ and tannic acid at $P<0.05$, respectively. CR-EE - Crotalaria Retusa ethanolic extract, CL-EE - Clerodendrum volubile ethanolic extract, CL-I - Clerodendrum volubile infusion, CSW-EE - cassava biogas slurry ethanolic extract, CSW-I cassava biogas slurry infusion. Both extracts of CR possess high $\mathrm{H} 2 \mathrm{O} 2$-scavenging potential compared to the others whose activities remained low at $250 \mu \mathrm{g} / \mathrm{ml}, 500 \mu \mathrm{g} / \mathrm{ml}$ and $1000 \mu \mathrm{g} / \mathrm{ml}$ (Figure 4). Only the ethanolic extracts of CR and CSW possess high hydroxyl radical scavenging power; whereas the infusion extract of $\mathrm{CL}$ and the ethanolic extract of CSW showed high DPPH radical scavenging ability compared to tannic acid (Figure 5). 


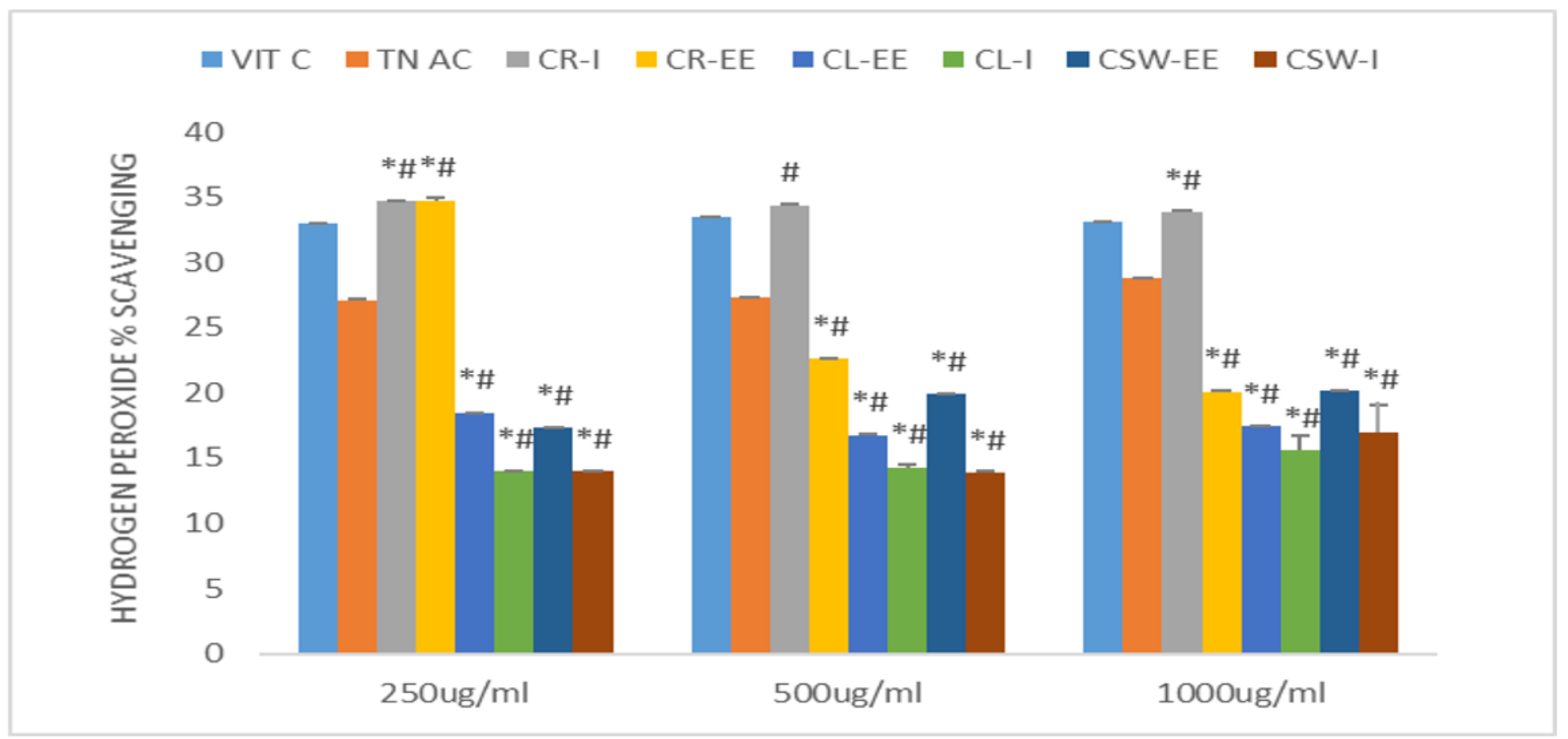

\section{Figure 4}

Hydrogen peroxide scavenging activities of the ethanolic and hot water infusion of Crotalaria retusa, Clerodendrum volubile, cassava biogas slurry extract. Each value represents a mean $\pm S D(n=2)$. "*" and "\#" indicate a significant difference in the effects of each sample compared to vitamin $\mathrm{C}$ and Tannic acid at $\mathrm{P}<0.05$, respectively. CR-EE - Crotalaria Retusa ethanolic extract, CL-EE - Clerodendrum volubile ethanolic extract, CL-I - Clerodendrum volubile infusion, CSW-EE - cassava biogas slurry ethanolic extract, CSW-I - cassava biogas slurry infusion.

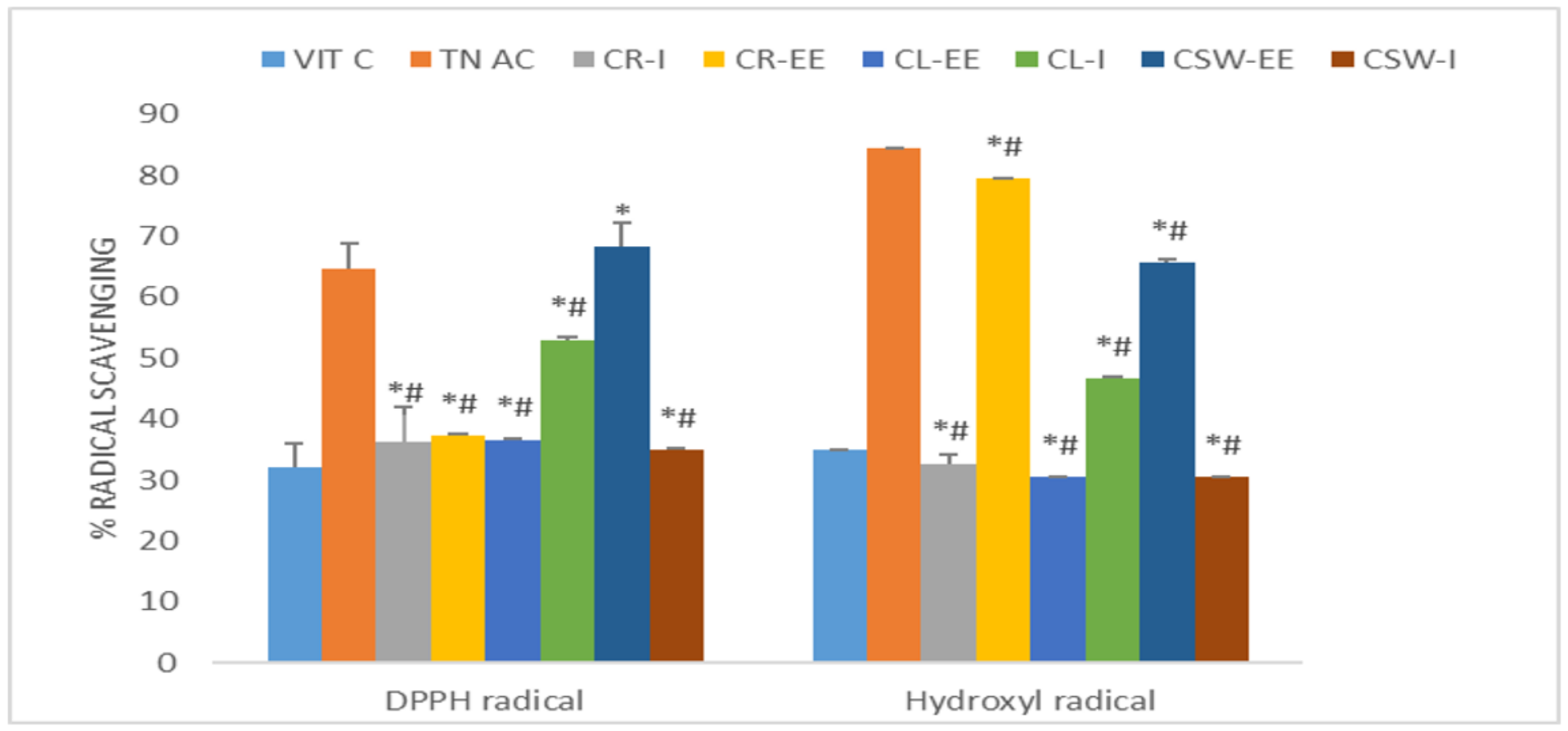

Figure 5 
The Radical Scavenging activities of the ethanolic and hot water infusion of Crotalaria retusa, Clerodendrum volubile, cassava biogas slurry extract. Each value represents a mean $\pm S D(n=2)$. "*" and "\#" indicate a significant difference in the effects of each sample compared to vitamin $C$ and Tannic acid at $P<0.05$, respectively. CR-EE - Crotalaria Retusa ethanolic extract, CL-EE - Clerodendrum volubile ethanolic extract, CL-I - Clerodendrum volubile infusion, CSW-EE - cassava biogas slurry ethanolic extract, CSW-I - cassava biogas slurry infusion. 